Nemanja Berber ${ }^{1}$

Agneš Slavić ${ }^{2}$

Marko Aleksić ${ }^{3}$

University of Novi Sad, Faculty of Economics in Subotica
ORIGINAL SCIENTIFIC ARTICLE doi:10.5937/ekonomika1903001B

Received: August 12. 2019.

Accepted: September, 09. 2019.

\title{
THE RELATIONSHIP BETWEEN CORPORATE SOCIAL RESPONSIBILITY AND CORPORATE GOVERNANCE ${ }^{4}$
}

\begin{abstract}
The concept that allows the balance between economic, social and environmental goals (as a concept of corporate social responsibility) represents a widely accepted business practice in the developed countries of the world. The growing demands of the business have pointed to the shortcomings of the management concepts that have been focused exclusively on profit. For these reasons, the problems, interests, and goals of the broader groups of stakeholders should be the components of a company's business and must be an integral part of corporate governance. The aim of the paper is to determine the relationship between corporate social responsibility (CSR) and corporate governance. The subject of research is the concepts of CSR and corporate governance, as well as their interconnectedness. The methodology includes an analysis of the available previous research results. The results of theoretical research indicate that there is a relation between both concepts, but that the link is not unambiguous.
\end{abstract}

Keywords: corporate social responsibility, corporate governance, sustainable development

JEL classification: A13, M14, O16

\section{ПОВЕЗАНОСТ КОРПОРАТИВНЕ ДРУШТВЕНЕ ОДГОВОРНОСТИ И КОРПОРАТИВНОГ УПРАВЉАҢА}

\begin{abstract}
Апстракт
Кониепт који омогућава баланс између економских, социјалних и еколошких цилева (као концепт корпоративне друштвене одгворности) представља широко прихваћену пословну праксу у развијеним землама света. Све већи захтеви послована указали су на недостатке досадашних менаимент кониепта орјенттисаних искључиво на профит. Управо из тих разлога проблеми, интереси и иильеви шире групе стејкхолдера треба да буду компоненте послована сваке компаније и морају бити саставни део корпоративног управљағьа. Циль рада је утврђиване повезаности између корпоративне друштвене одговорности (КДО)

\footnotetext{
${ }^{1}$ berber@ef.uns.ac.rs

${ }^{2}$ slavica@ef.uns.ac.rs

${ }^{3}$ marko.aleksic@ef.uns.ac.rs

${ }^{4}$ This paper is a part of the research project „Effects of corporate social responsibility in the field of human resources management on the performance and sustainability of organizations" financed within the "Short Term Projects of Special Interest for Sustainable Development in AP Vojvodina in 2019" by the Provincial Secretariat for Higher Education and Scientific Research of AP Vojvodina, Republic of Serbia.
} 
и корпоративног управљаюа. Предмет истраживана су кониепти КДО и корпоративног управљаюа, као и юихова међусобна повезаност. Методологија обухвата анализу доступних претходних истраживачких резултата. Резултати теоријског истраживана указују на постојане повезаности између сва кониепта, с тим да веза није једнозначна.

Къучне речи: корпоративна друштвена одговорност, корпоративно управъьане, одрживи развој

\section{Introduction}

The corporate social responsibility (CSR) is a voluntary concept that allows the balance between economic, social and environmental goals (Hopkins, 2005; Dahlsrud, 2008; Berber et al., 2018) and it is widely accepted business practice in the developed countries of the world. It is a concept that is related to the circular economy, which includes sustainable exploitation of material resources, social responsibility and more balanced development of the economy (Vukadinović \& Ješić, 2019). In this sense, modern business models are based on the idea that newly created value should represent value for all parties of interest, and it should include sustainable business conduct (Miletić, 2018). The growing demands of the business environment, like increasing of the government's restrictions on social and environmental issues, the demand of consumers for organic products, and strict requirement from investors (Ha et al., 2019) pointed to the shortcomings of the management concepts that have been focused exclusively on profit (Sekulić \& Pavlović, 2018). Corporate governance includes a set of relationships between a company's management, boards, shareholders and other stakeholders. For these reasons, the problems, interest, and goals of the broader groups of stakeholders (Blasi et al., 2018) should also the components of each company's business and must be an integral part of corporate governance, not just the relations between management and investors - owners. Also, reasons why it is important to make corporate governance more responsible lie in many cases of corporate fraud, accounting scandals and other organizational problems (lawsuits, resignations or even bankruptcy) (Duh, 2017).

The aim of the paper is to determine the relationship between corporate social responsibility (CSR) and corporate governance. The subject of research is the concepts of CSR and corporate governance, as well as their interconnectedness. The methodology includes an analysis of the available previous research results. The results of theoretical research indicate that there is a connection between all concepts, with the link being not unambiguous.

The work consists of three interconnected parts. In the first part, the authors discuss the emerging views on corporate governance. The second part deals with emerging views on corporate social responsibility. The third part is made up of the investigation of the interdependence of the two concepts mentioned above. Finally, in the conclusion, the authors point out the most important findings and possibilities for future research.

\section{Corporate Governance}

Contemporary business environment requires excellence in the field of management so that business organizations can achieve sustainable growth and development. The concept 
that applies to this requirement is corporate governance (Vuković et al., 2018). Corporate governance has numerous definitions and understandings. According to Gopalsamy, corporate governance (GC) is defined as "a combination of rules, regulations, laws, and examples of good practice that enable companies to attract financial and human capital to perform jobs efficiently and, therefore, to maximize value in the longer term, while respecting the aspirations of more stakeholders including society" (Gopalsamy, 2008). It is "the system by which companies are directed and controlled" (Cadbury, 2000, p. 8). Corporate governance refers to "a way of managing and controlling by means of principles, rules, customs, policies, and regulations. It offers a system that provides efficiency of processes and operations, reliable and transparent financial reporting, compliance with policies and regulations" (Yilmaz et al., 2017, p. 34).

Definitions of corporate governance tend to fall into two categories:

- "The first set of definitions is concerned with a set of behavioral patterns - the actual behavior of corporations, in terms of such measures as performance, efficiency, growth, financial structure, and treatment of shareholders and other stakeholders.

- The second set is concerned with the normative framework - the rules under which firms are operating, with the rules coming from such sources as the legal system, the judicial system, financial markets, and factor (labor) markets" (Claessens, 2006, p. 93).

The Organization for Economic Cooperation and Development (OECD, 2015), which published its Corporate Governance Principles in 1999, defines corporate governance as "a set of relationships between a company's management, its board, its shareholders and other stakeholders. Corporate governance also provides the structure through which the objectives of the company are set, and the means of attaining those objectives and monitoring performance are determined" (OECD, 2015, p. 9). "Corporate governance help policymakers evaluate and improve the legal, regulatory, and institutional framework for corporate governance, with a view to supporting economic efficiency, sustainable growth, and financial stability" (OECD, 2015, p. 3).

Good corporate governance in practice has proved to be of multiple importance. At the company level, good corporate governance brings easier and more affordable access to the new capital, which in the long run leads to greater competitiveness. The application of the highest standards actively promotes a strong corporate governance practice, where individuals are needed who are willing and able to devise and implement a good corporate governance policy. These companies will appreciate and reward their employees more than their competitors who are not aware of the benefits of corporate governance. Corporate societies often attract more investors willing to provide capital at a lower cost. In general terms, well-managed societies contribute to the national economy and the community, they are able to provide greater profits, to strengthen investor confidence in the capital market (World Bank, 2010), which leads to an improvement in the accountability system, thereby reducing the risk that employees in a business are deceived or doing business for their own benefit. Respecting the standards of good corporate governance helps in improving the decision-making process, leading to more successful operations and lower capital costs (World Bank, 2010).

From the perspective of companies, corporate governance is a set of rules that regulate relationships between shareholders - owners and management. Based on the understanding 
that company managers have the duty to act in the interests of shareholders, their basic role is to undertake business activities in order to increase the profits of the company and their shareholders. The question which arises is how owners can influence managers to manage their (owners) resources, not in self (managers) interests. By studying the complex nature of relations between owners and managers, the causes of the corporate governance problem are found in the separation of ownership from the management of the company (Babić \& Nikolić, 2011). In this relationship, "an agency problem occurs if managers can significantly influence earnings management in order to satisfy their own respective self-interests to the detriment of their shareholders" (Osemene et al., 2018, p. 211), so "compensation for top management must provide incentives to select and implement actions that increase shareholder wealth" (Načinović-Braje \& Galetić, 2019, p. 34).

Corporate governance is the structure of managing and overseeing a joint-stock company. In the widest form, this is the relationship between management and employees, or institutions that have invested in the corporation in order to make a profit. This suggests that corporate governance refers to the relationship between management and the owner. The practice of good corporate governance, which protects the interests of, first of all, minority shareholders is decisive for attracting foreign direct investment in each country. The efficiency of the work of the management in the corporation is enhanced by lifelong learning and practicing key procedures in decision making and fostering their realization, as well as control of execution (Sofronijević et al., 2013; Mihajlović, 2016, p. 5).

According to the World Bank, all definitions of corporate governance include several common elements:

- $\quad$ "Corporate governance is a system of relationships, defined by structures and processes.

- These relationships involve parties with different and sometimes contrasting interests.

- All parties are involved in the direction and control of the company.

- All this is done to properly distribute rights and responsibilities and thus increase long-term shareholder value" (World Bank, 2010, p. 6-8).

As it is seen from the abovementioned definitions corporate governance includes "the relationship between shareholders, creditors, and corporations; between financial markets, institutions, and corporations; and between employees and corporations" (Claessens, 2006, p. 94). This way of understanding of corporate governance points to the need of exploration of the relationships between corporate governance and other relevant areas, where corporate social responsibility is being more and more emphasized (Claessens, 2006; Jamali et al., 2008; Said et al., 2009; Jo \& Harjoto, 2012; Habbash, 2016; Oh et al., 2018; Dyck et al., 2019).

The following part of the text is related to the explanation of the corporate social responsibility concept. After that, the authors explored the relationship between both concepts and made several conclusions and recommendations for future research. 


\section{The Concept of Corporate Social Responsibility}

The increasing intensity of business changes is a reflection of today's modern business. Contemporary business challenges related to the growing competition, increasing customer and consumer demands, the introduction of new technologies, globalization, etc. Consumer awareness of environmental protection and socially responsible behavior has resulted in numerous actions by consumers and non-governmental organizations, which have forced many companies, and above all multinational companies, to take responsibility and engage in these initiatives (Nuševa, 2018, p. 259). This is specific for green tourism, which requires activities like "production of ecologically safe, recyclable and biodegradable products, using energy-efficient operations with minimal or no pollution, efficient waste management, conserving cultural and natural assets" (Gavrilović \& Maksimović, 2018, p. 40-41). Since there are present new and changing business conditions, it is important to implement new business models that will enable companies to achieve sustainable development and competitiveness. One of the possibilities is certainly the concept of corporate social responsibility.

The quality of a community has often been the subject of philanthropic activity of individuals, owners, and managers of a company, and, as a kind of responsible behavior towards the community, it was separated from business (Kotler \& Lee, 2009). Bowen made one of the first definitions of corporate social responsibility, where he stated that CSR the obligation of business people to seek those business policies, and make those decisions, or to follow those areas of action that are desirable in terms of the goals and values of the society (Bowen, 1953).

Carroll follows the evolution of a corporate social responsibility construct that began in the 1950s, which marks the modern era of CSR. These alternative topics include corporate social performance (CSP), stakeholder theory, and business ethics theory. During the 1990s, CSP continues to serve as a basic construct but continues to turn into alternative thematic frameworks (Carroll, 1999). Dahlsrud found that "socially responsible business concerns the responsibility of the organization and the undertaking of measures within the organization, which exceed its legal obligations and economic goals. These broader responsibilities encompass a range of issues, but are usually summarized as social and environmental concerns - social relations extend to society as a whole, and not just to social issues" (Dahlsrud, 2008). In his work, Dahlsrud (2008) pointed to the 37 definitions of CSR, which means that there are many views and understanding of this phenomenon.

Social responsibility implies that the company independently and voluntarily engages in activities that will contribute to the development and maintenance of the environment, since the concept of sustainable development is based on interrelations, interdependence, and complementarity of development policy and protection of environment along with obeying of ecological principles (Aničić et al., 2019). Thanks to the CSR, the company assesses the impact of its decisions on the natural, social, legal and economic environment in which it operates (Boljević et al., 2015, p. 117). "Corporate social responsibility is the business philosophy and the standard business within the legal framework of modern Western economies. The main goal of CSR is to introduce an interesting relationship between the previously mentioned primary interest to make a profit, scarcity of natural resources and growing demands for labor and frequent occurrences of exploitation" (Čibukčić, 2017, p. 176). 
Garriga and Melé tried to clarify the "mapping area" situation by classifying the main CSR theories and related approaches in four groups: (1) instrumental theories - in which the company is viewed as the only instrument for wealth creation and social activity are means to achieve economic results; (2) political theories - dealing with the strength of companies in the society and the responsible use of this power in the political sphere; (3) integrative theories - in which the company focuses on meeting social demands; and (4) ethical theories - based on the ethical responsibilities of companies in society. In practice, every CSR theory represents four dimensions related to profit, political performance, social demands, and ethical values. The authors emphasized the need to develop a new theory of business and social relations that will integrate these four dimensions (Garriga and Melé, 2004).

To summarize, CSR comprises economic performance, social accountability and environmental management (Dahlsrud, 2008) and it consists of four kinds of responsibilities: economic, legal, ethical, and philanthropy (Carroll, 1999; Berber et al., 2014, Berber et al., 2018). Based on the aforementioned concepts, GC and CSR, the authors decided to explore the relationship between them.

\section{The Relationship Between CG and CSR}

Companies increasingly accept the concept of CSR for gaining market reputation, better relations with stakeholders, handling public pressure and long-term strategic interests (Porter \& Kramer, 2002). In Porter and Kramer's views on CSR's strategic approach, one can find the arguments that the relationship between CSR activities of companies and society is considered as natural. In explaining critical and strategic natural interdependence, the authors explained that the company must integrate the social perspective into the basic business framework in order to gain greater benefit by a better understanding of competition and the adequate definition of a business strategy (Porter \& Kramer, 2006).

By providing CSR, companies can direct their behavior and influence the perceptions and expectations of stakeholders (Haniffa \& Hudaib, 2006; Jamali et al., 2008; Michelon \& Parbonetti, 2012). Corporate governance drives managers to set goals that relate to CSR (Jamali et al., 2008), while stakeholder theory links corporate governance and corporate social responsibility, suggesting that both should strive to improve stakeholder engagement and organizational legitimacy (Michelon \& Parbonetti, 2012). According to Stuebs and Sun (2015) good corporate governance leads to good CSR performances.

Several types of research on this theme showed that the relationship between CG and CSR exists, and that business success is influenced by both concepts, and their interconnections. Jamali et al. (2008) proposed a model that presents the main interfaces of CG and CSR (Figure 1), where CG is a necessary "building block" for CSR. The main interfaces between CG and CSR are in strategic leadership, stewardship, and progressive human resource management. While CG is increasingly conformance or compliance-driven, CSR falls on the other hand in the realm of voluntary social performance (p. 456). 
Figure 1: Relationship between CG and CSR
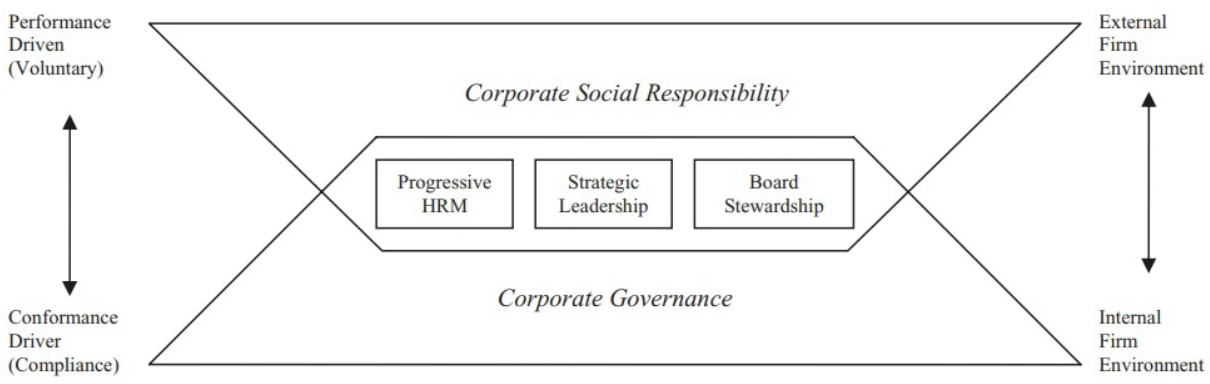

Source: Jamali et al., 2008, p. 456.

Mentioned authors found that "a company without an efficient long-term view of leadership, effective internal control mechanisms, and a strong sense of responsibility vis-à-vis internal stakeholders cannot possibly pursue genuine CSR, while CG is not entirely effective without a sustainable CSR drive because a company has to respond to the needs of its various stakeholders in order to be profitable and create value for its shareholders/owners" (Jamali et al., 2008, p. 457).

The different research of Said et al. (2009) pointed to the results that two CG variables, government ownership, and audit committee, are associated with the extent of CSR disclosures. They explored the relationship between corporate governance characteristics (board size, board independence, duality, audit committee, ten largest shareholders, managerial ownership, foreign ownership, and government ownership) and the extent of CSR disclosure (as a dependent variable). Government ownership and audit committee are positively correlated with the level of CSR disclosure.

Jo and Harjoto (2012) explored a sample of firms with CSR engagement in the United States during the 1993-2004 period and found that CSR can be understood as a missing link between CG and firm performance since there is a conflict of interest between stakeholders and shareholders. CSR is acting as a conflict-resolution device between stakeholders and shareholders (p. 65).

Chan et al. (2014) explored the 2004 annual report data for 222 listed Australian companies. They found that CSR disclosure is positively associated with good corporate governance. Organizations which provide more CSR information have better corporate governance ratings, those are larger organizations, they belong to higher-profile industries, and they are more highly leveraged (p. 59).

Ferrero-Ferrero et al. (2015) explored the mediating role of CSR in the relationship between board diversity and CSR performance. The sample was made of 146 companies listed in FTSE 100, DAX 30, and CAC 40 in 2009. The results showed that generational diversity enables a more effective design of vision and strategies to address financial and extra-financial aspects, and consequently, it encourages companies to adopt a sustainable approach to their businesses. This study concludes that generational diversity is a key component for improving good corporate governance codes.

Rodriguez-Fernandez (2016) found that companies registered on the Madrid Stock Exchange demonstrate positive relationships between CSR and financial performances. Social policies increment financial resources, and increased financial performances lead to greater 
social benefits. Therefore, board members should invest financial resources in developing policies that boost the levels of social behavior components in order to contribute globally to the improvement of society. Similarly, Wang and Sarkis (2017) found that companies that implemented CSR governance successfully generated good CSR outcomes and had better financial performances. CSR outcomes are found to be a mediator between CSR governance and financial performance.

Ali et al. (2017) explored the determinants of the CSR. They found that company size, industry sector, profitability, political, social, and cultural factors, and corporate governance mechanisms determine the CSR. In developed countries factors that determined the CSR disclosure were concerns of regulators, shareholders, creditors, investors, environmentalists, and the media. In developing countries, CSR reporting is more heavily influenced by the external forces such as international buyers, foreign investors, international media and international regulatory bodies (Ali et al., 2017, p. 273).

In their research in Lebanon, authors El Gammal et al. (2018) found that ethical practices fully mediate the relationship between corporate governance and corporate social responsibility towards stakeholders, customers, and employees. Gangi et al (2019) explored the sample of 142 banks from 35 countries in the period from 2011 to 2015 to investigate the relationship between CSR and banking risks. The found the positive impact of effective corporate governance mechanisms on banks' environmental engagement and that banks that are more sensitive to environmental issues also have less risk.

Based on the aforementioned research results it can be concluded that corporate governance and corporate social responsibility have positive relations, but that those relations are usually moderated by different organizational or external factors. Therefore, the relationship between the two concepts is very sensitive to the changes in the internal and external environment of the organizations.

\section{Conclusion}

Companies should not only create profits, but they should also act as subjects that enhance sustainable development and responsible behavior. Corporate practice needs to set the goals for sustainable development and respond to the needs of all stakeholders. Therefore, in order to create a competitive advantage, companies need to focus on productive roles in the global economy and become increasingly involved in the sphere of social responsibility, which creates long-term sustainability, meeting the needs of all suppliers, investors, and employees (Tai \& Chuang, 2014), and other stakeholders.

The aim of this paper was to determine the relation between CSR and corporate governance. Conclusions drawn from the previous analysis and discussion can be confirmed by the prevailing theoretical attitudes, as advocated by the famous theory of stakeholders, which emphasizes that the better the company builds and manages relations with the essential factors of the environment, it will be more successful over time (Barnett \& Salomon, 2012). Corporate governance is gaining in importance since it makes a significant contribution to increasing economic efficiency and market economy. Also, the nature of the CSR concept has been explained and the authors of this paper presented the main elements and issues of the concept. Namely, the practice and scope of CSR activities are based exclusively on cost-benefit analysis, that takes into account, on the one hand, invested capital (investments 
- disclaimer from current consumption for higher results in the future), while on the other hand, and especially the "invisible" and long-term benefits that an organization derives from the investment and implemented activities. It can be concluded that corporate governance and CSR have positive relations, but that those relations are usually moderated by different organizational or external factors. Therefore, the relationship between the two concepts is very sensitive to the changes in the internal and external environment of the organizations.

Regarding future research possibilities, this theoretical research and investigation of the previous results of the authors all around the world make the first step in generating the methodological frame for the investigation of the CSR and corporate governance and its relationship in the domestic economy.

\section{References}

Ali, W., Frynas, J. G., \& Mahmood, Z. (2017). Determinants of corporate social responsibility (CSR) disclosure in developed and developing countries: A literature review. Corporate Social Responsibility and Environmental Management, 24(4), 273294. DOI: https://doi.org/10.1002/csr.1410

Aničić, J., Aničić, D., \& Kvrgić, G. (2019). Sustainable growth and regional competitiveness of Serbian economy. Ekonomika, 65(2), 65-74. DOI: https://doi:10.5937/ ekonomika1902065A

Babić, V., \& Nikolić, J. (2011). Uticaj strukture vlasništva na performanse korporacija: poređenje tržišnih i tranzicionih ekonomija. U N. Janićijević i Lovreta, S.(Eds.). Novi metodi menadžmenta i marketinga u podizanju konkurentnosti srpske privrede (str. 75-85). Subotica: Ekonomski fakultet u Subotici, Beograd: Ekonomski fakultet i Naučno društvo ekonomista Srbije.

Barnett, M. L., \& Salomon, R. M. (2012). Does it pay to be really good? Addressing the shape of the relationship between social and financial performance. Strategic Management Journal, 33, 1304-1320. DOI: http://doi.org/10.1002/smj.1980

Berber, N., Slavić, A., \& Aleksić, M. (2018). Measuring corporate social responsibility: The GRI approach. In Đukić, T., \& Radenković Jocić, D. (Eds.). Proceedings of the International Scientific Conference: Quantitative and Qualitative Analysis in Economics ISC2018 (p. 145-154). Niš: University of Niš, Faculty of Economics.

Berber, N., Štanlg Šušnjar, G., Slavić, A., \& Baošić, M. (2014). Relationship between corporate social responsibility and human resource management-as new management concepts-in Central and Eastern Europe. Engineering Economics, 25(3), 360-369. DOI: https://doi.org/10.5755/j01.ee.25.3.4222

Blasi, S., Caporin, M., \& Fontini, F. (2018). A multidimensional analysis of the relationship between corporate social responsibility and firms' economic performance. Ecological Economics, 147, 218-229. DOI: https://doi.org/10.1016/j.ecolecon.2018.01.014

Boljević, A., Radovanović, M., \& Strugar, M. (2015). Korporativna društvena odgovornost u funkciji uspešnog poslovanja preduzeća. Anali Ekonomskog fakulteta u Subotici, (33), 115-127.

Bowen, H. (1953). Social Responsibilities of the Businessman. New York: Harper. 
Cadbury, S. A. (2000). The corporate governance agenda. Corporate Governance: An International Review, 8(1), 7-15.

Chan, M. C., Watson, J., \& Woodliff, D. (2014). Corporate governance quality and CSR disclosures. Journal of Business Ethics, 125(1), 59-73. DOI: https://doi.org/10.1007/ s10551-013-1887-8

Čibukčić, F. (2017). Corporate social responsibility in global and local companies of Southeast Europe. Industrija, 45(1), 175-188. DOI: https://doi.org/10.5937/ industrija45-9594

Claessens, S. (2006). Corporate governance and development. The World Bank rRsearch Observer, 21(1), 91-122.

Dahlsrud, A. (2008). How corporate social responsibility is defined: an analysis of 37 definitions. Corporate Social Responsibility and Environmental Management, 15(1), 1-13. DOI: https://doi.org/10.1002/csr.132

Duh, M. (2017). Corporate governance codes and their role in improving corporate governance practice. In Corporate Governance and Strategic Decision Making. IntechOpen. DOI: http://dx.doi.org/10.5772/intechopen.69707

Dyck, A., Lins, K. V., Roth, L., \& Wagner, H. F. (2019). Do institutional investors drive corporate social responsibility? International evidence. Journal of Financial Economics, 131(3), 693-714. DOI: https://doi.org/10.1016/j.jfineco.2018.08.013

El Gammal, W., Yassine, N., Fakih, K., \& El-Kassar, A. N. (2018). The relationship between CSR and corporate governance moderated by performance and board of directors' characteristics. Journal of Management and Governance, 1-20. DOI: https://doi. org/10.1007/s10997-018-9417-9

Ferrero-Ferrero, I., Fernández-Izquierdo, M. Á., \& Muñoz-Torres, M. J. (2015). Integrating sustainability into corporate governance: an empirical study on board diversity. Corporate Social Responsibility and Environmental Management, 22(4), 193-207. DOI: https://doi.org/10.1002/csr.1333

Gangi, F., Meles, A., D’Angelo, E., \& Daniele, L. M. (2019). Sustainable development and corporate governance in the financial system: Are environmentally friendly banks less risky?. Corporate Social Responsibility and Environmental Management, 26(3), 529547. DOI: https://doi.org/10.1002/csr.1699

Garriga, E., \& Melé, D. (2004). Corporate social responsibility theories: Mapping the territory. Journal of business ethics, 53(1-2), 51-71. DOI: https://doi.org/10.1023/ B:BUSI.0000039399.90587.34

Gavrilović, Z., \& Maksimović, M. (2018). Green innovations in the tourism sector. Strategic Management, 23(1), 36-42. DOI: https://doi.org/10.5937/StraMan1801036G

Ha, N. T. L., Ngoc, P. A. D., \& Velencei, J. (2019). Measuring corporate social performance. Serbian Journal of Management, 14(1), 193-204. DOI: https://doi.org/10.5937/sjm1418009

Habbash, M. (2016). Corporate governance and corporate social responsibility disclosure: evidence from Saudi Arabia. Social Responsibility Journal, 12(4), 740-754. DOI: https://doi.org/10.1108/SRJ-07-2015-0088 
Haniffa, R., \& Hudaib, M. (2006). Corporate governance structure and performance of Malaysian listed companies. Journal of Business Finance \& Accounting, 33(7-8), 1034-1062. DOI: https://doi.org/10.1111/j.1468-5957.2006.00594.x

Hopkins, M. (2005). Measurement of corporate social responsibility. International Journal of Management and Decision Making, 6(3-4), 213-231.

Jamali, D., Safieddine, A. M., \& Rabbath, M. (2008). Corporate governance and corporate social responsibility synergies and interrelationships. Corporate Governance: An International Review, 16(5), 443-459. DOI: https://doi.org/10.1111/j.14678683.2008.00702.x

Jo, H., \& Harjoto, M. A. (2012). The causal effect of corporate governance on corporate social responsibility. Journal of Business Ethics, 106(1), 53-72. DOI: https://doi. org/10.1007/s10551-011-1052-1

Michelon, G., \& Parbonetti, A. (2012). The effect of corporate governance on sustainability disclosure. Journal of Management and Governance, 16(3), 477-509. DOI: https://doi. org/10.1007/s10997-010-9160-3

Mihajlović, M. (2016). Odnos menadžmenta preduzeća i korporativnog upravljanja. Oditor - časopis za menadžment, finansije i pravo, 2(1), 4-10.

Miletić, V. (2018). Business model adjustment: A condition of an organization's sustainability on the market. Ekonomika, 64(3), 67-76. DOI: https://doi.org/10.5937/ ekonomika1803067M

Načinović-Braje, I., \& Galetić, L. (2019). Top management remuneration in a post-transition economy: Does company ownership make a difference?. Strategic Management, 24(2), 34-44. DOI: https://doi.org/10.5937/StraMan1902034N

Nuševa, D. (2018). Standardi održivog razvoja na globalnom tržištu kafe. Anali Ekonomskog fakulteta u Subotici, (39), 257-267.

OECD. (2015). G20/OECD Principles of Corporate Governance. Paris: OECD Publishing. DOI: http://dx.doi.org/10.1787/9789264236882-en

Oh, W. Y., Chang, Y. K., \& Kim, T. Y. (2018). Complementary or substitutive effects? Corporate governance mechanisms and corporate social responsibility. Journal of Management, 44(7), 2716-2739. DOI: https://doi.org/10.1177\%2F0149206316653804

Osemene, O. F., Adeyele, J. S., \& Adinnu, P. (2018). The impact of the ownership structure and board characteristics on earnings management in Nigeria's listed deposit money banks. Ekonomski horizonti, 20(3), 215-227. DOI: https://doi.org/doi:10.5937/ ekonhor 18032150

Porter, M. E., \& Kramer, M. R. (2002). The competitive advantage of corporate philanthropy. Harvard Business Review, 80(12), 56-68.

Porter, M. E., \& Kramer, M. R. (2006). The link between competitive advantage and corporate social responsibility.Harvard Business Review, 84(12), 78-92.

Rodriguez-Fernandez, M. (2016). Social responsibility and financial performance: The role of good corporate governance. BRQ Business Research Quarterly, 19(2), 137-151. DOI: https://doi.org/10.1016/j.brq.2015.08.001 
Said, R., Hj Zainuddin, Y., \& Haron, H. (2009). The relationship between corporate social responsibility disclosure and corporate governance characteristics in Malaysian public listed companies. Social Responsibility Journal, 5(2), 212-226. DOI: https://doi. org/10.1108/17471110910964496

Sekulić, V., \& Pavlović, M. (2018). Corporate social responsibility in relations with social community: Determinants, development, management aspects. Ekonomika, 64(4), 59-69. DOI: https://doi.org/10.5937/ekonomika1804057S

1. Sofronijević, A., Milićević, V., \& Ilić, B. (2013). Savremeni menadžment i promene vezane za automatizaciju intelektualnih poslova. Tehnika, 68(3), 533-538.

Stuebs, M., \& Sun, L. (2015). Corporate governance and social responsibility. International Journal of Law and Management, 57(1), 38-52. DOI: https://doi.org/10.1108/ IJLMA-04-2014-0034

Tai, F. M., \& Chuang, S. H. (2014). Corporate social responsibility. Ibusiness, 6(03), 117 130. DOI: http://dx.doi.org/10.4236/ib.2014.63013

Vukadinović, S., \& Ješić, J. (2019). Green jobs - potential for employment in the Republic of Serbia. Anali Ekonomskog fakulteta u Subotici, (41), 115-129. DOI: https://doi. org/10.5937/AnEkSub1941115V

Vuković, B., Pjanić, M., \& Kalaš, B. (2018). Analysis of the liquidity of agricultural companies of AP Vojvodina. Anali Ekonomskog fakulteta u Subotici, (39), 205-217.

Wang, Z., \& Sarkis, J. (2017). Corporate social responsibility governance, outcomes, and financial performance. Journal of Cleaner Production, 162, 1607-1616. DOI: https:// doi.org/10.1016/j.jclepro.2017.06.142

World Bank. 2010. Corporate governance manual : second edition (English). Washington, DC: World Bank. Retrieved Jun 20, 2019, from http://documents.worldbank.org/ curated/en/490901468134091644/Corporate-governance-manual-second-edition

Yilmaz, O. D., Kurt-Gumus, G., \& Aslanertik, B. E. (2017). Corporate governance and voluntary disclosure: content analysis on borsa istanbul hospitality industry companies. Turizam, 21(1), 34-44. DOI: https://doi.org/10.18421/trz21.01-03 